\section{Rootstock-induced Differences in Sap Flow of 'Granny Smith' Apple}

\author{
Ismail A. Hussein ${ }^{1}$ \\ Horticulture Section, Desert Research Center, Cairo, Egypt
}

Marshall J. McFarland ${ }^{2}$

Stephenville Agricultural Research and Extension Center, Texas A\&M University System, Route 2 Box 00, Stephenville, TX 76401

Additional index words. Malus domestica, transpiration, water use, stem gauge

\begin{abstract}
Two-year-old, greenhouse-grown, potted 'Granny Smith' apple (Malus domestica Borkh.) trees grafted on seedling, M.7 EMLA, or Mark rootstock were subjected to water stress by withholding irrigation for three successive days. Sap flow rates were measured with steady-state, heat-balance stem gauges; daily water use was measured with an electronic balance; and instantaneous transpiration was measured with a diffusion porometer. Differences in the sap flow among the three rootstocks were observed by the third day of stress treatment. The cumulative sap flow over the 3-day stress period was higher for trees on seedling and M.7 EMLA rootstocks than for those on Mark. Cumulative sap flow was reduced on the second and third days of water stress compared to sap flow in the control. The diurnal peak of sap flow rate was flattened on the second and third days of stress compared to the pattern for the control and first day of stress treatment. In general, the trees on the standard rootstock (seedling) were least affected by the water stress; trees on the full dwarf rootstock (Mark) were the most affected. Good agreement between cumulative sap flow measurements and gravimetric measurements indicates that the steady-state, heat-balance method is practical and accurate.
\end{abstract}

Apple rootstocks vary in degree of size control and in relation to such characteristics as anchorage, bearing, disease and insect susceptibility, and water use (Andriani et al., 1992; Rom et al., 1987). Jones et al. (1992) reported that the response of 'Cox's Orange Pippin', 'Golden Delicious', and 'A120/3' to water stress resulted in more acoustic emissions from plants on the dwarfing M.9 rootstock than from those on the more vigorous M.25 rootstock for a given water potential. The water potential threshold at which acoustic emission (from cavitation or embolism formation in the xylem vessels) began to occur was different for the two rootstocks; however, Chandel et al. (1990) reported that 'Starking Delicious' apple trees on MM.111, M.9, MM.106, and MM.104 rootstocks were less affected by water stress than those on seedling or $\mathrm{M} .25$ rootstocks.

The steady-state, heat-balance technique is practical and can measure sap flow rate and sap flow accumulation over time for small woody ornamentals and trees with great precision (Cohen et al., 1993; Steinberg et al., 1989, 1990a, 1990b, 1991a, 1991b; Zajicek et al., 1990). Our objective was to investigate the

\footnotetext{
Received for publication 8 Nov. 1993. Accepted for publication 12 May 1994. Approved for publication as Texas Agricultural Expt. Station publication TA31588. This research was supported by the Egyptian National Agricultural Research Program. The cost of publishing this paper was defrayed in part by the payment of page charges. Under postal regulations, this paper therefore must be hereby marked advertisement solely to indicate this fact.

${ }^{1}$ Professor.
}

${ }^{2}$ Professor and Resident Director of Research. influence of rootstock-scion combinations on water consumption of 'Granny Smith' apple using steady-state, heat-balance stem gauges.

\section{Materials and Methods}

The study was performed in a greenhouse at the Texas A\&M Univ. Agricultural Research and Extension Center, Stephenville (lat. $32^{\prime} 12^{\circ} \mathrm{N}$, long. $98^{\prime} 13^{\circ} \mathrm{W}$ ), from Mar. to Sept. 1993. In early March, 2-year-old 'Granny Smith' apple trees grafted on M.7 EMLA, Mark, or seedling rootstocks were planted in 15 -liter pots filled with a sandy clay loam soil. They were bare-root trees that had been grown 1 year after budding in a local nursery. The graft union of all trees was kept $\approx 5 \mathrm{~cm}$ above the soil surface. The seedling rootstock is vigorous and produces a large tree size that tolerates adverse moisture and poor soil conditions (Rom and Carlson, 1987). M.7 EMLA is a virus-free, semidwarf rootstock and dwarfs to $55 \%$ to $70 \%$ of standard size. It is considered widely adapted to diverse soil conditions. Mark is a dwarf rootstock and produces trees at $\approx 35 \%$ to $45 \%$ of standard size and is sensitive to drought stress (Good Fruit Grower, 1993; Rom, 1987). The trees were cut back to $60 \mathrm{~cm}$ above the soil surface after planting and subjected to the recommended horticultural practices to promote vegetative growth under greenhouse conditions. Six weeks before installing stem gauges, the lateral shoots that had developed $\leq 25 \mathrm{~cm}$ above the graft union were defoliated and smoothed by removing all dead and loose bark and sanding any protuberances, without injuring the living bark. Trunk diameter was measured with calipers at the stem gauge placement site. In July, the potted trees were grouped at random into two sets. Each set of nine trees (three rootstocks $\times$ three replications) served as a treatment set in the first experiment (Expt. A) and served as a control set in the repeat of the experiment (Expt. B).

During each experiment, the control trees were watered each morning to the point of drainage, but the stress-treatment trees were not watered for three successive days. The first day of stress treatment refers to the second 24$\mathrm{h}$ period following the last irrigation. All trees were fully watered every 1 or 2 days, except during the stress-treatment periods.

To measure the sap flow rate, a fourchannel stem gauge was attached to the base of the stem $\approx 15 \mathrm{~cm}$ above the graft union. The gauges were constructed in the laboratory using the same basic materials Steinberg et al. (1989) described - a flexible heater $20 \mathrm{~mm}$ in diameter, $22 \mathrm{~mm}$ wide, and $62 \mathrm{~mm}$ long with 50 -ohm resistance. After the gauges were placed on the tree trunks, each gauge was covered with aluminum foil to reduce the effect of external radiation. Enough gauges were constructed to leave each gauge in place throughout the experimental periods. A regulated DC power supply was used to supply 4.6 $\mathrm{V}$ to the heater. A $21 \mathrm{X}$ datalogger with an AM416 multiplexer (Campbell Scientific, Logan, Utah) was used to log and process the signals of eight gauges. The datalogger was programmed to record and interpret the output from eight gauges every $15 \mathrm{sec}$ and store the average every $30 \mathrm{~min}$ by using DGSF Dynagage flow analysis software (Dynamax, Houston, Texas). The data was downloaded from the datalogger cassette to a personal computer each morning. With only one AM416 multiplexer, eight was the maximum number of gauges that could be operated simultaneously in each experiment. The sap flow measurement of the remaining tree in each experimental set of nine trees was made separately within each experiment period to have sufficient replications for statistical analysis.

Before the first experiment, each installed gauge was tested for operation and accuracy by comparing the observed sap flow rate and accumulation to gravimetrical measurements over 5 days, and gauges and balance measurements agreed. To measure cumulative water loss gravimetrically during the gauge test and experiment periods, the potted trees were weighed $( \pm 91 \mathrm{~g})$ daily on an electronic balance at 8:00 AM central daylight time (CDT). The pots were wrapped with white plastic film throughout the experiment so that the only water loss was due to transpiration. Leaf transpiration rates were measured at 9:00 AM, noon, 3:00 PM, and 6:00 PM CDT in each experiment period with a steady-state porometer (model 1600; LI-COR, Lincoln, Neb.). Measurements of three mature leaves per tree were used as replications to calculate the mean leaf transpiration rate on a unit area basis.

The total leaf count and leaf area were determined for each tree at the end of each experiment. The mean leaf area of each tree was determined from the areas of 10 mature leaves that were measured with a portable area 
meter (model LI-3000; LI-COR). At the end of the last experiment, tree height was measured. Growth rate and other morphological features were similar, presumably because the stress periods were limited to a few days.

Experiments A and B were performed from 27 June to 7 July and 25 July to 4 Aug., respectively. During the experiment periods, greenhouse air ranged from 25 to $35 \mathrm{C}$, and relative humidity was $40 \%$ to $75 \%$.

All data were statistically analyzed according to a completely randomized design by using the SAS (1985) statistical analysis procedure. Significance of differences among treatment means was judged with Duncan's multiple range test at $P \leq 0.05$. Accumulated sap flow was regressed on cumulative weight loss, measured gravimetrically, in each of the experiments. Indicated regression for each rootstock and regression slopes and intercepts were tested for homogeneity (Steel and Torrie, 1980).

\section{Results}

Daily sap flow. Sap flow differences developed during the stress periods (Table 1). In Expts. A and B, there were no differences in sap flow among trees on the three rootstocks for the first day of stress. By the third day of stress, the trees on the seedling rootstock had the highest sap flow by a factor of two to three, compared to trees on M.7 EMLA and Mark.

Diurnal pattern of sap flow. The diurnal pattern of sap flow, measured by the sap flow gauge, showed little difference between the control trees and stressed trees during the first day of stress (Table 2). The second and third days of stress flattened the typical bell-shaped transpiration curve noted for the control trees. When viewed cumulatively for each rootstock, the control, and each day of stress, the differences due to the rootstocks are obvious (Figs. $1-4)$. The trees on the seedling rootstock had the highest sap flow in all treatments, followed by M.7 EMLA and Mark. However, the differences between M.7 EMLA and Mark were not significant at $P \leq 0.05$.

Mean transpiration rate. Measured with the diffusion porometer, differences in leaf transpiration rate among trees on the different rootstocks were obtained for the control and each day of the stress treatment (Table 3 ). The mean transpiration rate of trees grafted on seedling or M.7 EMLA rootstocks was significantly higher than those on Mark for the controls. By day 3 of the stress treatment, transpiration rate differences were noted between trees on seedling and Mark rootstock for both experiments. For Expt. B, the seedling rootstock tree also differed significantly from the M.7 EMLA rootstock tree. The mean leaf transpiration rates for the stress treatments were less than half the rates for the controls for the first day of the stress treatment and about one-tenth that of the control for some rootstocks on the third day.

Diurnal transpiration rate. The highest transpiration rates for the control and the first day of stress treatments occurred at the noon measurement (Table 3). On the second and
Table 1. Daily sap flow (kilograms), measured by stem gauge, of 'Granny Smith' apple on three distinct rootstocks in response to water-stress treatments for 3 days. The values are the averages of three replications.

\begin{tabular}{|c|c|c|c|c|c|c|c|c|}
\hline \multirow[b]{2}{*}{ Stock $^{2}$} & \multicolumn{4}{|c|}{ Expt. A } & \multicolumn{4}{|c|}{ Expt. B } \\
\hline & $\begin{array}{c}\text { Control } \\
\text { daily mean }\end{array}$ & Day 1 & Day 2 & Day 3 & $\begin{array}{c}\text { Control } \\
\text { daily mean }\end{array}$ & Day 1 & Day 2 & Day 3 \\
\hline \multicolumn{9}{|c|}{ Sap flow (kg) } \\
\hline Seedling & $0.29 \mathrm{~b}$ & 0.27 & $0.19 \mathrm{a}$ & $0.29 \mathrm{a}$ & 0.35 & 0.33 & 0.17 & $0.32 \mathrm{a}$ \\
\hline M.7 EMLA & $0.33 \mathrm{ab}$ & 0.28 & $0.23 \mathrm{a}$ & $0.16 \mathrm{~b}$ & 0.33 & 0.29 & 0.19 & $0.16 \mathrm{~b}$ \\
\hline Mark & $0.36 \mathrm{a}$ & 0.30 & $0.12 \mathrm{~b}$ & $0.12 \mathrm{~b}$ & 0.27 & 0.26 & 0.09 & $0.11 \mathrm{~b}$ \\
\hline
\end{tabular}

${ }^{2}$ Mean separations in columns by Duncan's multiple range test at $P \leq 0.05$.

Table 2. Sap flow of 'Granny Smith' apple during 3-hour periods for three distinct rootstocks in response to water stress in two experiments. Values are means of three replications.

\begin{tabular}{|c|c|c|c|c|c|c|c|c|}
\hline \multirow[b]{2}{*}{ Time $(\mathrm{CDT})^{2}$} & \multicolumn{4}{|c|}{ Expt. A } & \multicolumn{4}{|c|}{ Expt. B } \\
\hline & $\begin{array}{c}\text { Control } \\
\text { daily mean }\end{array}$ & Day 1 & Day 2 & Day 3 & $\begin{array}{c}\text { Control } \\
\text { daily mean }\end{array}$ & Day 1 & Day 2 & Day 3 \\
\hline \multicolumn{9}{|c|}{ Sap flow $(\mathrm{kg})$} \\
\hline 6:00 AM & 0.00 & 0.00 & 0.00 & 0.00 & 0.00 & 0.00 & 0.00 & 0.00 \\
\hline 9:00 Ам & 0.00 & 0.01 & 0.02 & 0.00 & 0.00 & 0.08 & 0.01 & 0.01 \\
\hline $12: 00$ noon & 0.07 & 0.08 & 0.04 & 0.05 & 0.09 & 0.10 & 0.06 & 0.03 \\
\hline 3:00 PM & 0.10 & 0.10 & 0.04 & 0.07 & 0.10 & 0.10 & 0.05 & 0.05 \\
\hline 6:00 PM & 0.08 & 0.09 & 0.04 & 0.06 & 0.10 & 0.02 & 0.03 & 0.03 \\
\hline 9:00 PM & 0.02 & 0.00 & 0.00 & 0.00 & 0.00 & 0.00 & 0.00 & 0.01 \\
\hline
\end{tabular}

${ }^{\mathrm{z}} \mathrm{CDT}=$ central daylight time.

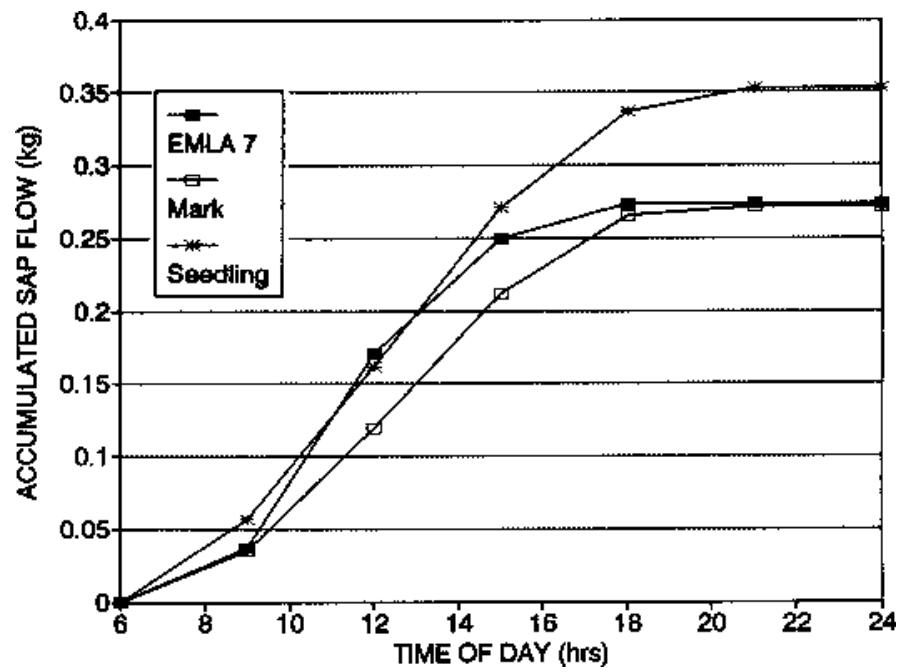

Fig. 1. Diurnal sap flow of 'Granny Smith' apple on three distinct rootstocks in the absence of water stress (control). Each data point is the mean of two experiments with three replications in each experiment.

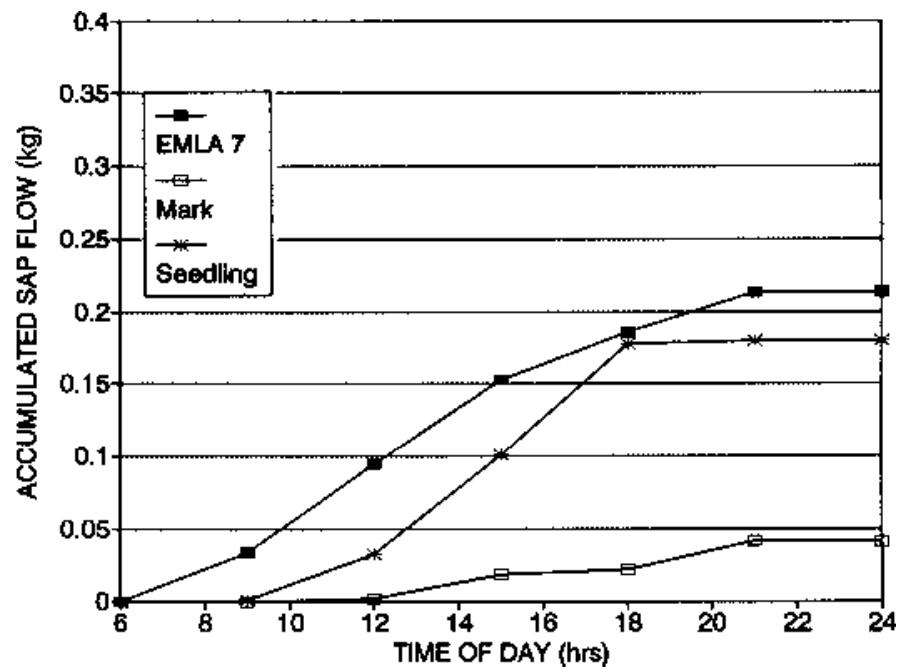

Fig. 2. Diurnal sap flow of 'Granny Smith' apple on three distinct rootstocks after the first day of water stress. Each data point is the mean of two experiments with three replications in each experiment. 


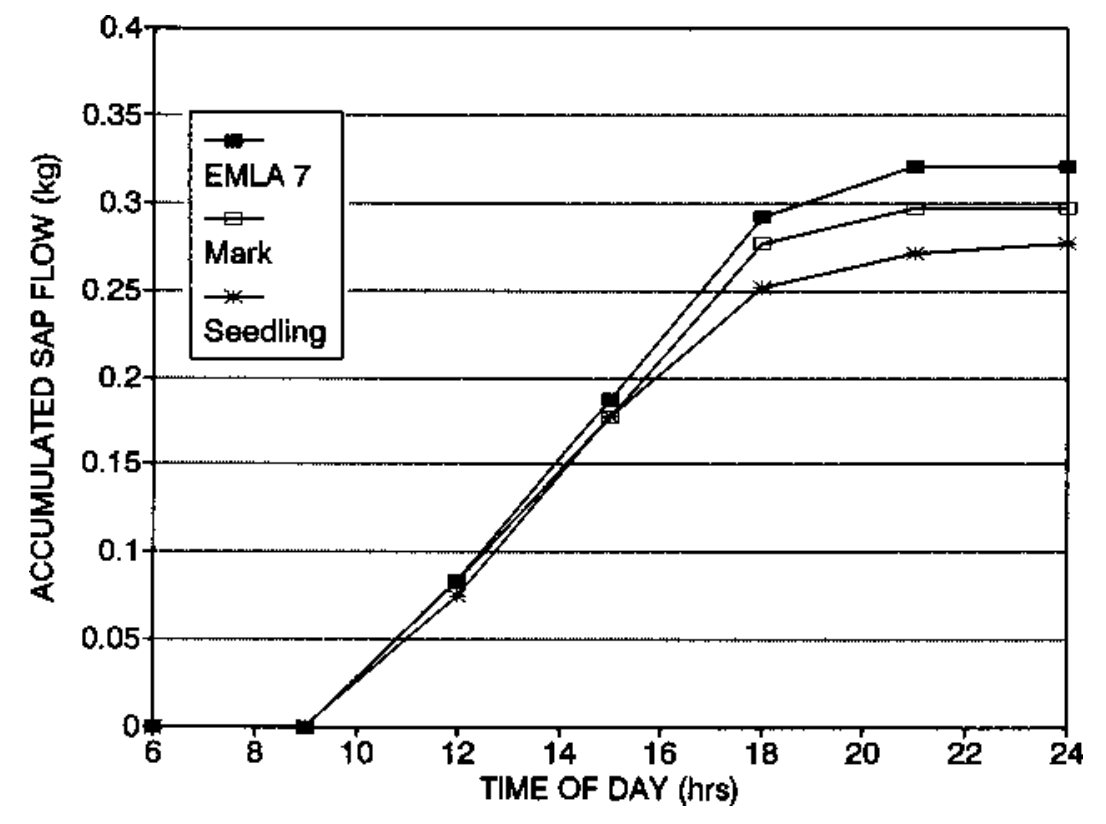

Fig. 3. Diurnal sap flow of 'Granny Smith' apple on three distinct rootstocks after the second day of water stress. Each data point is the mean of two experiments with three replications in each experiment.

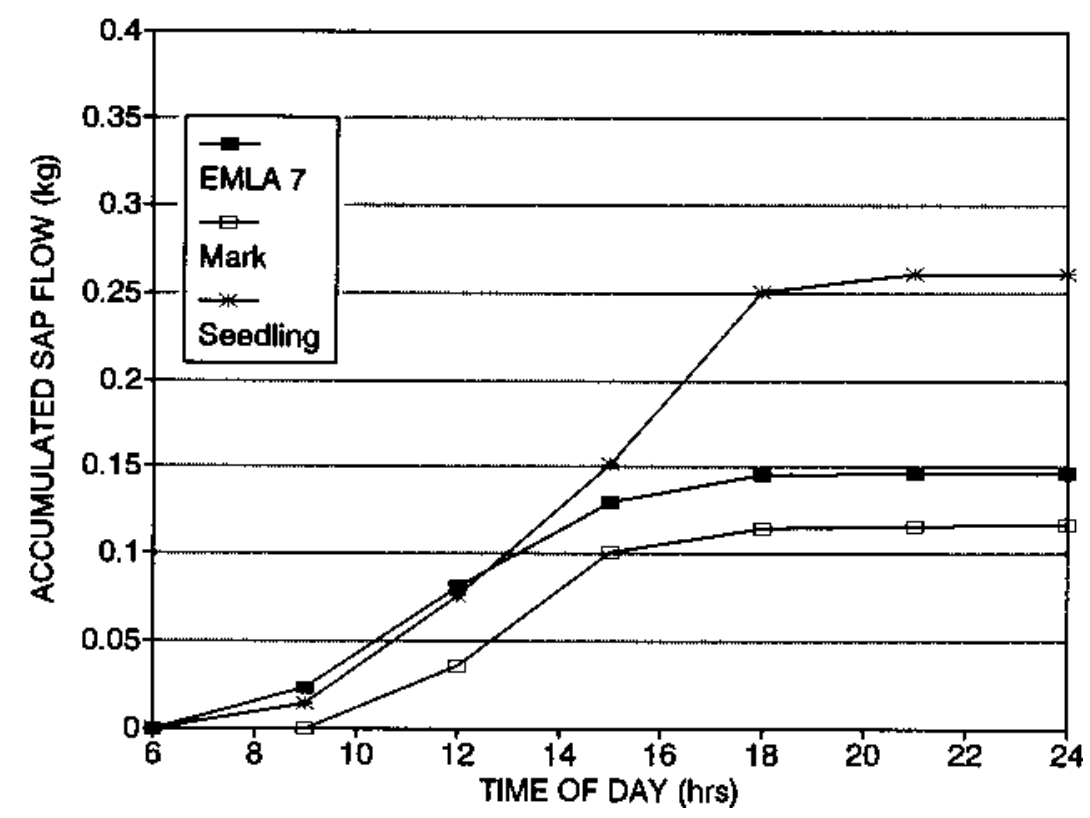

Fig. 4. Diurnal sap flow of 'Granny Smith' apple on three distinct rootstocks after the third day of water stress. Each data point is the mean of two experiments with three replications in each experiment.

Table 3. Mean and diurnal leaf transpiration rates (micrograms per square centimeter per second) of 'Granny Smith' apple trees grafted on three different rootstocks in response to water-stress treatments measured by steady-state porometer in two experiments. Values are the averages of three replications.

\begin{tabular}{|c|c|c|c|c|c|c|c|c|}
\hline \multirow[b]{2}{*}{ Variable $^{\mathrm{z}}$} & \multicolumn{4}{|c|}{ Expt. A } & \multicolumn{4}{|c|}{ Expt. B } \\
\hline & $\begin{array}{c}\text { Control } \\
\text { daily mean }\end{array}$ & Day 1 & Day 2 & Day 3 & $\begin{array}{c}\text { Control } \\
\text { daily mean }\end{array}$ & Day 1 & Day 2 & Day 3 \\
\hline \multicolumn{9}{|l|}{ Rootstock } \\
\hline Seedling & $12.29 \mathrm{a}$ & 5.82 & 4.64 & $1.39 \mathrm{a}$ & $11.89 \mathrm{a}$ & 5.93 & 4.94 & $1.59 \mathrm{a}$ \\
\hline M.7 EMLA & $11.08 \mathrm{a}$ & 5.56 & 3.92 & $1.30 \mathrm{ab}$ & $11.20 \mathrm{a}$ & 5.84 & 4.24 & $1.07 \mathrm{~b}$ \\
\hline Mark & $6.29 \mathrm{~b}$ & 4.81 & 3.48 & $1.02 \mathrm{~b}$ & $5.98 \mathrm{~b}$ & 4.31 & 3.66 & $0.90 \mathrm{~b}$ \\
\hline \multicolumn{9}{|l|}{ Time $(C D T)^{y}$} \\
\hline $9: 00 \mathrm{AM}$ & $8.18 \mathrm{~b}$ & 5.41 & $6.0 \mathrm{a}$ & $1.41 \mathrm{ab}$ & $8.34 \mathrm{bc}$ & 5.90 & $6.14 \mathrm{a}$ & $1.18 \mathrm{~b}$ \\
\hline 12:00 noon & $15.74 \mathrm{a}$ & 6.82 & $3.19 \mathrm{bc}$ & $0.88 \mathrm{c}$ & $14.12 \mathrm{a}$ & 6.69 & $4.12 \mathrm{~b}$ & $0.83 \mathrm{~b}$ \\
\hline 3:00 PM & $10.07 \mathrm{~b}$ & 4.98 & $4.19 \mathrm{~b}$ & $1.66 \mathrm{a}$ & $10.57 \mathrm{~b}$ & 4.93 & $4.20 \mathrm{~b}$ & $1.65 \mathrm{a}$ \\
\hline 6:00 PM & $5.59 \mathrm{c}$ & 4.37 & $2.68 \mathrm{c}$ & $1.02 \mathrm{bc}$ & $5.74 \mathrm{c}$ & 3.92 & $2.66 \mathrm{~b}$ & $1.08 \mathrm{~b}$ \\
\hline
\end{tabular}

${ }^{2}$ Mean separations in columns by Duncan's multiple range test at $P \leq 0.05$.

${ }^{\mathrm{y}} \mathrm{CDT}=$ central daylight time. third day of the stress treatments, the rate tended to be lowest at noon.

Cumulative sap flow vs. cumulative weight loss. The 24-h weight change of each potted tree as measured with the electronic balance was compared to the weight loss measured by the stem gauges before and during the experiments. The two measurement systems correlated well (Fig. 5). Tests of regression homogeneity indicated that there were no significant differences in slopes or intercepts among the three distinct rootstocks in each experiment. Therefore, a single regression equation was developed for each experiment. In Expt. A, the intercept was not significantly different from zero; thus, the equation was recalculated by forcing the intercept through zero. The regression coefficient of the resulting equation $(\mathrm{y}=0.98 \mathrm{x})$ was not significantly different from 1.0. In Expt. B, the intercept in the resulting equation $(y=0.014+0.92 x)$ was significantly different from zero, and the regression coefficient was significantly $<1.0$ (Fig. 5).

Tree morphology. All trees in the treatments were essentially the same size with the same leaf area at the experiments' conclusions. The stem diameter was larger for the trees on the seedling rootstock than for those on the other rootstocks (Table 4), but this was most likely due to the nature of the dwarfing characteristics of the M.7 EMLA and Mark rootstocks, as opposed to the effects of the water stress treatments. No conclusions should be drawn regarding the effects of the waterstress periods on tree morphology.

\section{Discussion}

In general, moisture stress affected the sap flow of the standard (seedling) rootstock the least and the sap flow of the tree on the full dwarf (Mark) rootstock the most. The semidwarfing rootstock (M.7 EMLA) was intermediate. By the third day of stress, differences were noted between all treatment trees and the control trees.

The cause of the differences in the sap flow induced by the rootstocks is not known, but it might be related to differences in root characteristics, xylem anatomy, or other features of the hydraulic architecture from the roots to the bud union or of the bud union itself. More studies are needed to explain the relationship between xylem anatomy and the morphology of stock-scion combination, hydraulic architecture, and sap flow.

The diurnal pattern of the sap flow rate over daylight hours was not present on stress days 2 and 3 for stressed trees, probably due to stomatal closure and a resulting decrease in transpiration rate in response to water stress. Transpiration rate is affected by leaf area and structure, stomatal aperture, and environmental conditions (Kramer, 1983). However, no significant differences in leaf area were found between trees, regardless of rootstock and the environmental conditions (e.g., radiation and wind), because all trees were essentially the same. Carlson et al. (1967) reported that transpiration rates in young 'Delicious' apple trees 

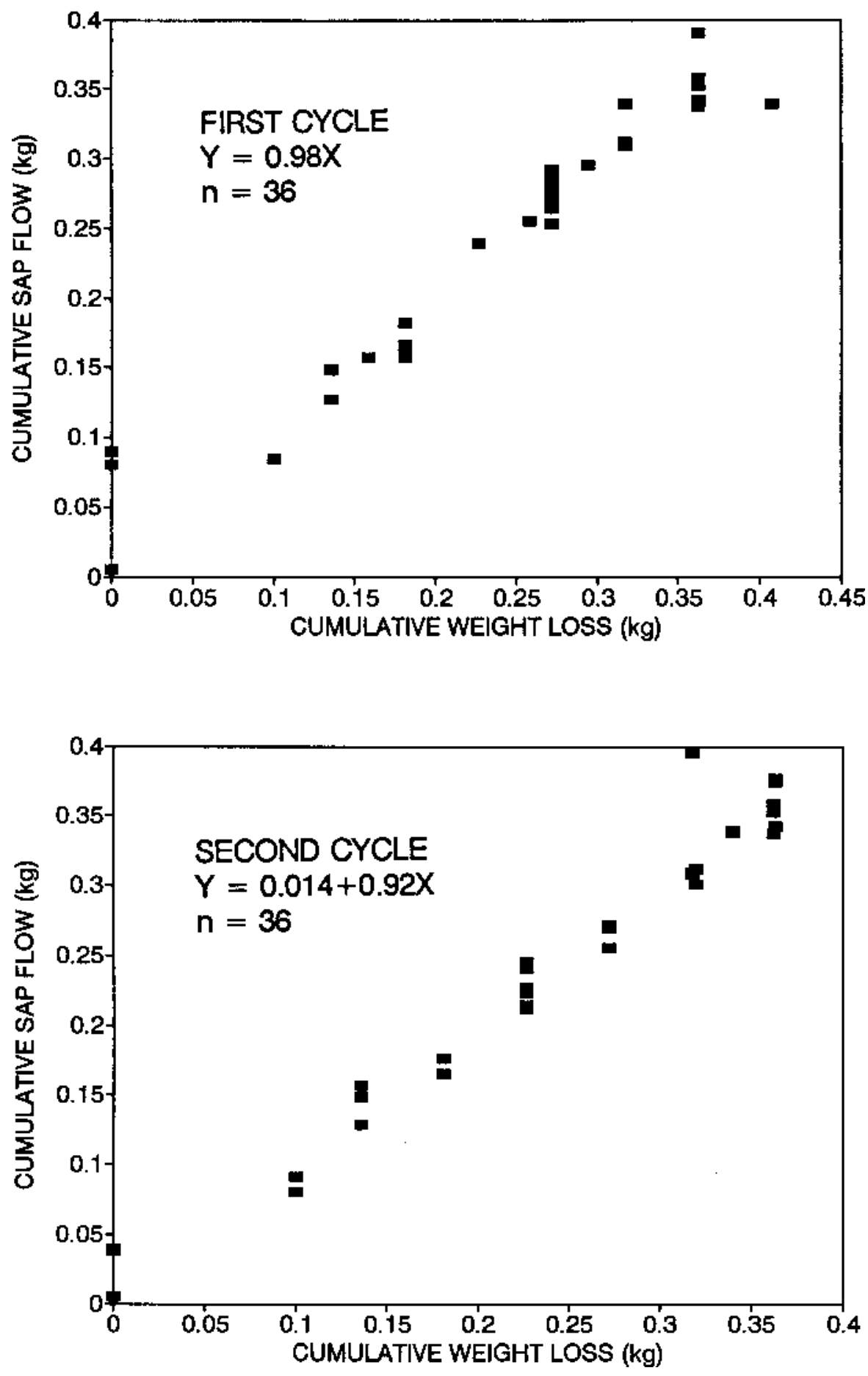

Fig. 5. Comparison of steady-state, heat-balance, measurements with sap flow of 'Granny Smith' apple on three distinct rootstocks with gravimetric measurements of weight change due to transpiration.

on M.9, M.26, M.2, MM.106, and MM.111 rootstocks were similar under conditions of no water stress.

The diurnal pattern of transpiration rate over daylight hours is a function of radiation when soil water is not limiting. The leaf transpiration peak is normally at local solar noon. When water intake at the root surfaces is inadequate to meet leaf transpirational demands, the change in the leaf's water status leads to stomatal closure and, therefore, pre-
Table 4. Morphological measurements of 'Granny Smith' apple trees on three distinct rootstocks. Values are means of three replications for each experiment.

\begin{tabular}{lccc}
\hline \hline Rootstock & $\begin{array}{c}\text { Tree ht } \\
(\mathrm{m})\end{array}$ & $\begin{array}{c}\text { Stem diam } \\
(\mathrm{mm})\end{array}$ & $\begin{array}{c}\text { Leaf area } \\
\left(\mathrm{m}^{2}\right)\end{array}$ \\
\hline Seedling & 1.39 & $23 \mathrm{a}$ & 37.6 \\
M.7 EMLA & 1.16 & $17 \mathrm{~b}$ & 29.0 \\
Mark & 1.32 & $15 \mathrm{~b}$ & 33.7
\end{tabular}

${ }^{\mathrm{z}}$ Mean separation in columns by Duncan's multiple range test at $P \leq 0.05$.

the balance measurements agreed. Therefore, we conclude that the stem gauge data, evaluated by gravimetrical measurements, were highly accurate, which is consistent with Steinberg et al.'s (1989) work.

\section{Literature Cited}

Andriani, M.G., G. Miali, and G. Fabrizio. 1992. The response of two apple cultivars to different rootstocks and irrigation regimes in Tavoliere di Puglia. Hort. Abstr. 62:2734.

Carlson, R.F. 1967. Growth response of several rootstocks to soil water. HortScience 2:109_ 110.

Chandel, J.S. and J.S. Chauhan. 1990. Effect of rootstocks and water stress on foliar nutrient (Fe, $\mathrm{Mn}, \mathrm{Zn}$, and $\mathrm{Cu}$ ) composition of Starking Delicious apple. Hort. J. 3(1-2):10-14.

Cohen, Y., S. Takenchi, J. Nozaka, and T. Yano. 1993. Accuracy of sap flow measurement using heat balance and heat pulse methods. Agron. J. 85:1080-1086.

Good Fruit Grower. 1993. What is Mark swelling? Good Fruit Grower 49:23.

Jones, H.G., K.H. Keith, K.H. Higgs, and A. Bergamini. 1992. The use of ultrasonic detractors for water stress determination in fruit trees. Hort. Abstr. 62:3668.

Kramer, J.P. 1983. Water relations of plants. Academic, New York.

Rom, R.C. and R.F. Carlson. 1987. Rootstocks for fruit crop. Wiley-Interscience, New York.

SAS Institute. 1985. SAS user's guide and SAS statistical procedures. SAS Institute, Inc., Cary, N.C.

Steel, R.G. and J.H. Torrie. 1980. Principles and procedures of statistics. McGraw-Hill, New York.

Steinberg, S.L., C.H.M. van Bavel, and M.J. McFarland. 1989. A gauge to measure the mass flow of sap in stems and trunks of woody plants. J. Amer. Soc. Hort. Sci. 114:466-472.

Steinberg, S.L., C.H.M. van Bavel, and M.J. McFarland. 1990a. Improved sap flow gauge for woody and herbaceous plants. Agron. J. 82:851859.

Steinberg, S.L., M.J. McFarland, and J.W. Worthington. 1990b. Comparison of trunk and branch sap flow with canopy transpiration in pecan. J. Expt. Bot. 41:653-659.

Steinberg, S.L., J.M. Zajicek, and M.J. McFarland. 1991a. Short-term effect of uniconazole on the water relations and growth of Ligustrum. J. Amer. Soc. Hort. Sci. 116:460-464.

Steinberg, S.L., J.M. Zajicek, and M.J. McFarland. 1991b. Water relations of hibiscus following pruning or chemical growth regulation. J. Amer. Soc. Hort. Sci. 116:465-470.

Zajicek, J.M., S.L. Steinberg, and M.J. McFarland. 1990. Effect of the amount of dormant pruning on growth and water use of containerized crape myrtle (Lagerstroemia $\times$ Faurieri var Tuscarora). J. Environ. Hort. 9:88-91. 